\title{
Subject to Truth: Before and After Governmentality in Foucault's 1970s
}

In this paper I situate Foucault's governmentality analytics between his first lecture course (On the Will to Know, 1970-71) and his first course after his two "governmentality" lectures (On the Government of the Living, 1979-80). The lectures are interconnected by a shared interpretation of Sophocles' Oedipus Rex as well as by different but related obsessions with the production of truth: the earlier, with truth as fact; the latter, with truth as self-relation. The former analyses discourses of truth, law, inquiry and sovereignty in ancient Greece. The latter focuses on early Christian individual manifestations of truth (baptism, penance, and spiritual direction) forming a genealogy of confession and, Foucault suggests, of western subjectivity itself. This paper uses the analytical categories of governmentality, usually used to analyse regimes of government, to perform a comparative reading of the lecture courses, charting the continuities and ruptures in their various studies of episteme, techne, identities, ethos and problematisations. This suggests that the earlier lectures outline the birth of the sovereign-juridical compact that modern governmentalities would emerge through and against, while the later lectures use the term "governmentality" less, but enable the analysis of the conduct of conduct to progress to the ethical scale of self-formation.

Keywords: Foucault; Governmentality; Truth; Subjectivity; Christianity; Confession

Acknowledgements: This paper was written up during a British Academy Mid-Career Fellowship. I am also indebted to Colin Gordon, Greg Hollin, and Denise McCoskey for reading the paper and Lynn Fotheringham for providing several helpful references. 


\title{
Subject to Truth: Before and After Governmentality in Foucault's 1970s
}

\author{
"If you are obliged to tell the truth it is because, without knowing it, despite \\ everything, there's a bit of Oedipus in you too." (Foucault, 1979-80 [2014], 302)
}

\section{Foucault's governmentality}

The use of governmentality as an analytical framework to understand the conduct of conduct, and the analysis of governmentalities within actually existing scales of regulation, has risen exponentially within geography and beyond over the last twenty years (see Crampton and Elden, 2007, Ettlinger, 2011, Legg, 2014, Rutherford and Rutherford, 2013a, 2013b, Schlosser 2008). Foucault offered a threefold definition of governmentality (a type of power, the pre-eminence of governmental power over time, and the governmentalisation of the state) in his famous lecture on $1^{\text {st }}$ February 1978 (Foucault, 1977-78 [2007], 108-09, translated in Burchell, et al., 1991). At its heart, governmentality concerns the supplementing of older forms of sovereign power with more subtle ways of influencing behaviour (modern forms of which were termed biopower, or, power over life). The latter conducts behaviour from a distance so as to secure semi-natural processes (such as population, society, or economy). But these definitions were packed around, in 1977-78 and the following year's second "governmentality" lecture course (Foucault, 1978-79 [2008]), with complementary and challenging concepts that would prove equally central to the governmentality corpus, such as the conduct of conduct and counter-conducts, liberalism as the play of freedoms, and pastoral power. Foucault described "governmentality" in 1979 as "... no more than a proposed analytical grid for these relations of power [the conduct of conduct]" (Foucault, 1978-79 [2008], 186).

There has been some reflection within geography on the impact of the publication of the full "governmentality" lecture courses, situating the lectures within their broader intellectual (Elden, 2007) and political (Barnett, 2011) context. But since the explicitly "governmentality" lectures have been translated there has been a stream of further Collège de France courses released, from Foucault's first (Foucault, 1970-71 [2013], henceforth referenced as WtK) to his last (Foucault, 198384 [2011]). These lectures show Foucault fleshing out research that appears in work he published during his lifetime (Elden, 2005), addressing, at least: prisons, penal control and punitive society; psychiatry, normal behaviour and disciplinary care; society and government; and the classical world as a place where the self becomes a scale for internalising politics and of ethical self-formation (see Philo, 2012).

Geographers have worked less with the later work on ethics and the ancient world, although there have been various engagements with Foucault's thought on sexuality (Howell, 2007), geographies of 
moral regulation (Legg and Brown, 2013) and technologies of self-help (Nally and Taylor, 2015). This paper's detailed reading of Foucault's research on ancient and medieval Europe will suggest that there is much here for geographers to dwell upon in terms of space and governmentality, and space within Foucault's broader thought more generally, for instance: the rejection by ancient philosophers of thought that was considered too situated, too embodied; the competitive space of the Greek agon in the formation of truth and the legal ordering of cities; spaces of purification, exile, democracy and the classical city; the signification of water in baptism and early Christianity more broadly; the metaphorical churches of Satan in Christian hearts; the seemingly homogenous notion of "western civilisation"; and the theatrical staging of Greek tragedy/truth. The conclusion will suggest ways in which those interested in the relationships between society and space could pursue this material and develop some of its often speculative insights.

Beyond geography there is a growing body of work that variously submits the historical conjectures in Foucault's later works to critical textual and historical analyses. These include Fuggle (2013) on the Apostle Paul, Ojakangas (2010) on the notion of Pauline (non-)biopolitics and on the Christian rupture, not origin, of modern governmentalities, which are much more easily traced to classical Greece and Rome (Ojakangas, 2012). Others have explored the methodological and philosophical developments in the later Foucault. These include Bernauer and Mahon (2005) on ethics as the realm that provokes resistance, Davidson (2005) on the relationship between knowing oneself and ascetics, Koopman (2013) on ethics' response to the problematizations that genealogy provides and Veyne (1993) on the persistent historical interest in an ontology of the present in Foucault's ethical works. But few of these texts draw upon the recently published material, and none of them compare lecture courses as a means of tracking developments in Foucault's thought.

\section{Foucault's 1970s}

In this paper I would like to argue that an engagement with Foucault's lecture courses is vital for contextualising and developing the thriving governmentality school within and beyond geography. It would be impossible to encapsulate the range, diversity, and contradictions of the entire lecture courses here, or in any paper. So I would like to provide a comparative reading of two lecture courses, Foucault's first, and his first after the two "governmentality" lecture courses of 1977-9. ${ }^{1}$

Delivered nearly 10 years apart, a comparative reading across Foucault's 1970s allows broader shifts in Foucault's thinking to be acknowledged (from archaeology to genealogy, from discourse to selfrelations) but also for us to identify unacknowledged continuities (his long-standing interest in the classical world, which was his sole empirical focus in his lectures from 1979 on, and an abiding interest in the production of truth). Governmentality analytics are prefigured in the 1970-71 lectures 
through interests in relationships between ancient law, space and sovereignty, and supplemented in the 1979-80 lectures with genealogies of the use of truth in self-other relationships. While Foucault's concepts circulate widely in academia it is rare, in geography more than elsewhere, to find sustained and detailed readings of the vast empirical and analytical work that went in to producing these concepts. This paper compares these two linked but very different lecture courses to provide such a reading.

First comes the Lectures on the Will to Know, published in 2013 (henceforth Will to Know, presented alongside his inaugural lecture, published as Foucault, 1970 [1981]). These lectures explore (over a decade before Foucault's famous publications on the ancient world) the intersection of discourses of truth, law, and philosophy in seventh to fifth centuries BCE Greece. The second course to be considered followed The Birth of Biopolitics course of 1978-79, which was explicitly framed as the second governmentality course (see Legg, 2009). It was published as On the Government of the Living (henceforth Government of the Living) in English in 2014. Seemingly without warning, those who attended the packed lecture hall on $9^{\text {th }}$ January 1980 found themselves transported back to the ancient world and would, over the following year, be lectured on the Oedipus tragedy and the early modern Christian church's experiments with baptism, penance, spiritual direction and confession (Foucault, 1979-80 [2014], henceforth referenced as GoL). The final destination of this journey was the modern western subject developing through, for instance, homo oeconomicus (see Elden forthcoming-b, 103) and homo criminalis (Harcourt, 2011, 119), here tracked back to the Christian soul, as forged through the institutional regulation of individual relations to truth.

It is this command to tell and know the truth that, Foucault suggests, marks the intimate intrusion of governmentality into self-conduct. This genealogical focus on the subject and the effects on bodies of the conduct of truth would seem to be in contrast to the first lectures of 1970-71, which perform an archaeology of the emergence of juridical facts and the measurement of law, space, money and time in ancient Greece. But the two lecture courses are intrinsically and extrinsically linked. In terms of the latter, both use Sophocles' Oedipus tragedy as a pivotal study (as did Foucault, 1981 [2014]). But, intrinsically, both lectures focus on the production of truth: the earlier, with truth as fact; the latter with truth as self-relation. The aim of this piece is not to examine how Foucault's archaeological and genealogical interests interlock here (see Behrent, 2012) nor to test his interpretations of classical and theological texts (see McSweeney, 2007, Ormand, 2013 on the reception of his earlier publications. Schmitz, 2008, 153-154, summarises classicist criticisms of Foucault's work in terms of the silencing of women, narrow source materials, the conflation of Athenian with "Greek" thought, and over generalisations. There are few substantial responses to his lecture courses as yet). Rather, I would like to suggest how these two courses alternately pre-figure 
and develop many of the interests articulated in the 1977-79 governmentality lectures. This is not an intellectual history or a philosophical enquiry into the development of Foucault's interests in power as they pivot onto the ethics of self-formation (see Elden, forthcoming-a, forthcoming-b).

Rather I hope this introduction will suggest some ways by which the non-specialist (who may not have an interest in post-Homeric Greece or the early Christian world...) can engage with the theoretical and methodological tools that these two courses offer up. This is not to shy away from many of the common criticisms which Foucault has faced, and which can also be laid here; his Eurocentrism; his gender blindness; his lack of clarity on temporal transitions and the presentist focus of his work; the lingering hint of structuralism, especially in the Will to Know; and the residual pessimism that remains the sub-script to this "scribe of power" (Said, et al., 1993 [2004], 214), no matter how much he insisted:

"I hate power, I hate the idea of power, and that is what people don't understand... how can we talk of relations of power if we do not at the same time talk about the phenomenon of resistance, since precisely for me power is not on one side and resistance on the other, but you have a reciprocal relationship, there is power only where there is resistance." (Foucault, et al., 2012, 106, 108 speaking two days before giving his final lecture on the first "goverernmentality" course, on April 3rd 1978).

To present and compare the lectures I will take up the analytical categories I have used to explore Foucault's 1977-78 lectures on population (Legg, 2005), and will be introduced in each section below. They will here serve as a framework for comparatively reading the two courses, seeking out their shared interests in truth and the (dis)continuities in Foucault's thought across the 1970s. These similarities and differences will be brought together sequentially before reflecting on the two texts' relation to what became known as governmentality, providing, if you will, a fivefold coming together of halves:

\begin{tabular}{|l|l|l|}
\hline Analytic & Will to Know 1970-71 & Government of the Living 1979-80 \\
\hline Episteme: the will to truth & $\begin{array}{l}\text { From wild sovereignty to } \\
\text { judicial testimony }\end{array}$ & Truth through the subject \\
\hline $\begin{array}{l}\text { Techne: govern the city, govern } \\
\text { the human }\end{array}$ & $\begin{array}{l}\text { Infrastructures of the } \\
\text { City-State }\end{array}$ & Infrastructures of the soul \\
\hline Identity: the birth of you? & $\begin{array}{l}\text { The witness and the } \\
\text { citizen }\end{array}$ & Tell me who you are \\
\hline $\begin{array}{l}\text { Ethos and problematisation: } \\
\text { democracy, revolt, guilt, sin }\end{array}$ & To the people & To the soul \\
\hline Governmentality & $\begin{array}{l}\text { The vertigo of a familiar } \\
\text { past }\end{array}$ & Before fearless speech \\
\hline
\end{tabular}




\section{Episteme: the Will to Truth}

“... when we ask the question of what this will to truth has been and constantly is, across our discourses, this will to truth which has crossed so many centuries of our history;... then what we see taking shape is perhaps something like a system of exclusion, a historical, modifiable, and institutionally constraining system." (Foucault, 1970 [1981], 54, emphasis added)

Colin Gordon (2015) has suggested that Foucault's Government of the Living lectures mark an "alethic" turn to an "aletheological" analysis (aletheia being ancient Greek for truth or disclosure), based on Foucault's neologism alethurgy, meaning "manifestation of truth". This turn to questions of truth certainly marks his early 1980s works, where truth was examined in schemes including: avowal or confession; veridiction (determinations of the truth); parrhesia (truth telling or fearless speech); as well as alethurgy (Gordon, 2014, 517). But the truth is also the subject of his Will to Know lectures, even though the functioning and analysis of this truth is wholly different. If episteme relates to the historical a priori which dictate what can be considered true or false in a particular time and space, then the definition of truth itself must be vital: "In other words, it is not the truth that so to speak administers its own empire, that judges and sanctions whose who obey or disobey it. It is not true that the truth constrains only by truth." $(G o L, 96)$

In his inaugural lecture at the Collège de France, delivered the week before the beginning of the Will to Know lectures, Foucault outlined how he believed discourses were controlled through three great systems of exclusion: forbidding speech (about, for instance, sex or politics); division (of madness or the criminal); and the will to truth (see the quote above, and $W t K, 52-54$ ). Truth here, then, is a way of controlling something else; namely, discourse's powers and dangers, its chance events, and its ponderous, formidable materiality; "truth effects" work here on other discourses, forcing them to proclaim and prove their truths, not on subjects and souls, as in the Government of the Living.

With remarkable foresight Foucault (1970 [1981], 70-71) explained his methodology and future research interests, which played out fairly accurately over the next decade. His first method was that of "critique", exposing practices of exclusion; his second method was that of "genealogy" and would examine how objects were constituted through discourses with specific conditions and norms. In terms of truth, the latter would have to wait until the Government of the Living.

\section{The Will to Know: from wild sovereignty to judicial testimony}

The Will to know lectures open by seeking out truth exclusions in the very origin of western philosophical thought. Foucault shows how Aristotle identified knowledge not as that which 
emerged from sensation and pleasure, but from specific forms of evidence, cause, and end product (WtK, 5-11). These qualities were clearly lacking in the Sophists, who could be hired to tutor one in the rhetorical arts of politics but whose knowledge was too materialistic, and too embodied, to qualify as truth (a sensation not unknown to most geographers, $W t K, 50,61$ ). But rather than work towards the present from this origin of western philosophy, Foucault took this exclusion as part of a series of classical exclusions that were attempting to regulate truth claims in new, logical, and deductive forms. To understand the pre-history of these truth struggles he turned to Archaic judicial and poetic discourses to identify the mythical and kinship forms of truth-testing that had to be overcome in the post-tyrannical, pre-democratic Greek city-states.

In contrast to the witness-based testimony trials of classical civilisation (c. 500 BCE to $336 \mathrm{BCE}$ ), Foucault drew upon existing classical scholarship to suggest that the Archaic period (c. 750 BCE to $500 \mathrm{BCE})$ saw the truth of disputes established through confrontation and oath-taking. Here there is no third figure (whether magistrate, judge or witness) to speak the truth; truth itself is the third figure, though this figure is called forth through taking an oath to the gods. The effect of the oath was immediate, even if the false oath-taker might be struck down by divine retribution at a later date. Taking the oath contained a risk, whether of future misfortune or of immediate death (as in the cases of women forced to throw themselves off a cliff into the sea, to be rescued by a marine divinity if they spoke the truth, or of a child exposed to the elements, $W t K, 85)$. In the later classical world truth would be called forth in the proven space of sovereignty, the law court. For the "prelaw" world "... the test of truth appeals to an unlimited and wild sovereignty." (WtK, 78):

"...being exposed or exposing someone to undefined danger. Taking the oath of truth or exposing oneself to the danger of blows, the thunderbolt, the sea, wild beasts - this has the same form and the same operational property. In the archaic judicial practice, the word of truth is not linked to light and looking at things; it is linked to the obscurity of the future and uncertain events." (WtK, 85)

The development of the new judgement system of krinein marks the taming of this wild sovereignty (dikazein). It marked the emergence of judges, who would also take an oath, of a sense of dikaion (what is just) alongside alēthēs (the true), and the connection of political discourses of sovereignty and discourses of knowledge in which that link is truth $(W t K, 96)$. This is not an abstract truth but a practical necessity as a city without truths would be vulnerable to divine retribution: "A city without truth is a threatened city. Threatened by mixtures, impurities, unfulfilled exclusions. The city needs the truth as a principle of division. It needs discourses of truth as it needs those who maintain the 
divisions." (WtK, 187). This would be a truth manifested through the application of the law, of nomos, as detailed in the techne section below.

Before moving on to the episteme of the Government of the Living we must consider the bridging study of Sophocles' Oedipus Rex (its popular Latin title, being Oedipus the King in English or Oidipous Turannos in Greek). Perhaps the most famous of the Greek tragedies, Oedipus recalls the legendary hero who solved the riddle of the Sphinx. Unbeknownst to Oedipus, having been raised in Corinth, he was the abandoned child of King Laius and Queen Jocasta of Thebes. On hearing that he was doomed to be killed by his own son, Laius had commanded his child to be murdered, but Jocasta had ordered a servant to do the deed. The servant had left the baby on a mountain top to die of exposure but a shepherd had rescued him. In later life Oedipus would kill a stranger (who was actually his father, King Laius) and, as a reward for freeing the city from the curse of the Sphinx, would claim the throne of Thebes and the dowager Queen Jocasta (who was actually his mother) as his wife. The play focuses on the plague that Thebes came to suffer from and the revelation that it was due to the city's failure to catch the murderer of King Laius, Oedipus himself, who in the course of the play is prophesied to be brother and father to his own children, and son and husband to his own mother. The shepherd and the servant's evidence eventually comes forth and the truth is acknowledged, upon which Jocasta hangs herself and Oedipus puts out his eyes before asking to be exiled.

Foucault's reading is that the play marks the confrontation of different forms of knowledge and constraints on systems of truth, which emerged in Greece and still ring true in western societies. The flashes and blazes of prophesies and doomed truth are ignored, with Oedipus's preferring instead to compile his own facts so that he can deduce the truth $(W t K, 192)$. The Will to Know also includes a March 1972 lecture on "Oedipal Knowledge" (for another rendering from May 1973 see Foucault, 1973 [2001], 16-34), recounting the tragedy in which "... he who unleashed the dogs is himself the prey; the trail on which he set them takes them back to the point where he is waiting for them." (WtK, 229) These hounds are the different knowledge forms, from listening, sight, God, witnesses, leaders, slaves, testimony, and hidden truths, that are flushed out by investigation. These pieces of knowledge come together in twos to show that Oedipus was the product of too many halves; son to two fathers; regent, but also agent of regicide; murderer and child; husband and son; father and brother; seeker and sought. The political element to the truth which Oedipus coerced knowledge into revealing is that Oedipus was not just King (Rex) but Tyrant (Turannos): an outsider who seized the throne by outwitting the Sphinx but who refused to listen; who forced out testimonies on pain of torture; and who ruled too much (note here the parallels to the modern 
insistence that the sovereign must withdraw from the economy, who not only should not but could not rule there, Foucault, 1977-78 [2007], 71). But it was fundamentally a problem of powerknowledge, of not knowing that one's knowledge was not enough to govern well, that seals Oedipus's fate.

\section{The Government of the Living: truth through the subject}

Foucault would take up the knowledge-truth relationship in the Government of the Living but with the emphasis falling much more heavily on the truth, though the connections to the Will to Knowledge lectures were explicitly made: "Basically what I would like to do and know that I will not be able to do is write a history of the force of truth, a history of the power of truth, a history, therefore, to take the same idea from a different angle, of the will to know." $(G o L, 101)$ This is his project of alethurgy (the manifestation of truth) which is at the heart of the lectures' epistemic politics and which is outlined, after an introductory lecture, by three opening lectures on Oedipus. The first emphasises the role of the servants and the diviners of the gods; the second focuses on Oedipus's tyranny and witnessing; while the final lecture briefly considers Oedipus's (non)punishment.

The tragedy is here revisited not as a play of knowledges but of the manifestation of truths, with Oedipus being "...a drama of multiple truths, of abundant truths, of truths in excess." (GoL, 25, Foucault later revists Oedipus as a tale about a tyrant refusing to heed the parresia of his brother-inlaw, see Foucault, 1982-83 [2010], 51). The truths are revealed, again, through a law of halves, with two sides coming together to propel along the narrative to the ultimate truth of Oedipus's identity. This identity is read through the metaphor of the sumbolon, a broken ceramic object in which one half was given to a messenger as guarantee of the authenticity of the message, which was proven when the fragments were reunited into a whole, a symbol of authenticity $(G o L, 32)$. Apollo and the oracle come together to speak the truth but not in the form of a whole story; Oedipus and Jocasta speak of memory plagued by doubt; the servant and the shepherd recall their partial roles in the tragedy. The ancient, sovereign alethurgy of the gods (oracular consultation) meets the emergent, testimonial alethurgy of the servants (interrogation) between which the King's veridiction is tyrannically blind to the sumbolon of his patricide and his birth (GoL, 34-40):

"... Oedipus finds that he is himself this sumbolon, this shard broken in two, with a Theban half and a Corinthian half. At the end of the play he who was fragmented finds his unity again, or again ends up double. Oedipus is these two halves and at the same time a double being, and the monstrosity of Oedipus consists precisely in 
being perpetually double, since he is both son and husband of his mother, father and brother of his children." (GoL, 33)

The contrast which frames this sumbolon is precisely that outlined in the Will to Know, the two great routes to the manifestation of truth, the religious giving way to the judicial (GoL, 39). What, then, is the point of repeating this interpretation of Oedipus, trapped between an ancient and a new alethurgy, besides showing that, rather than a utilitarian relationship to knowledge, "Alethurgy, the manifestation of the truth, is much more than making known" $(G o L, 75)$ ?

It is the role of the shepherd and the servant. Not because of what they say, but because of how they say " 'I,' 'myself,' 'I was there myself,' 'I myself saw,' 'I gave with my own hands,' 'I received with my own hands,' 'ego.'” (GoL, 48): “...without what could be called this point of subjectivation in the general procedure and overall cycle of alethurgy, the manifestation of the truth would remain incomplete." (GoL, 73, emphases added) This is what Foucault goes on to study over the following year; the role of "I", the "autos", the "myself" in alethurgy or the rights of veridiction (speaking the truth). This first-person emerges through the witness, through the recounted travel story, and leads, Foucault speculates, to the "myself" of Descartes ( $G o L, 50$, see the section on identities below). The challenge for the remaining lectures in 1980 was to show how "...the government of men, the manifestation of truth in the form of subjectivity, and the salvation of each and all has been established in our civilisation?" (GoL, 75) This epistemic interest was pursued by Foucault not in ancient Greece but in early modern Europe; the techniques and identity claims he found there directing him to nothing less, he suggested, than the origin of the western subject.

\section{Techne: govern the city, govern the human}

Oedipus, in denying one of the divinations of his true nature, dismissed this claim as driven by jealousy regarding his ploute (wealth), turanni (power/tyranny) and tekhnē (GoL, 51). The latter refers to technical knowledge, with Oedipus's form (tekhnē tekhnēs) being the supreme art of governing men in general. But by the fourth century CE techne will also come to encompass spiritual direction; the art of directing souls. We will return to this sense in discussing the analytics of identity below, but techne here will address the technical knowledge and operative side of governmentalities; how interventions into the world were made and the geographies that resulted. If the epistemic interests of the two lecture courses overlap, then their technical analyses clearly diverge; while the Will to Know examined infrastructures of the City-State, the Government of the Living examined the infrastructures of the soul. 


\section{The Will to Know: infrastructures of the City-State}

"We can begin to see the need for a discourse which will not sing of the sovereign, but of the nomos itself, of the principle of distribution, its value and wisdom, the origin on which it is founded, and the order whose reign it establishes not only over men, but over the stars, seas, animals, and plants." (WtK, 163)

Foucault argued that the emergence of the krinein system of justice not only began to shade out the ancient and mythological truth-test of oath taking, but also created new forms of sovereign space. Internal to specific contestations this included the law court but, externally, krinein was also linked to new forms of political power, notably a City-State system which allowed for measurement, comparison and judgement over space and time, setting calendars, boundaries and measurements (WtK, 111). This would provide a broader sense of justice, including that of exact returns and common measure in commerce (through the institution of money), consent and mutual agreement in voluntary understandings. Justice was taken out of the hands of an expert (Oedipal) King and became part of a natural, divine and human order (WtK, 119). Justice would thus become the law as nomos, that is, law applied to the order of the world (also see Legg, 2011). This would also be the focus of the Security, Territory, Population (Foucault, 1977-78 [2007]) lectures, where law intersected with modern capillary techniques and normalising measures.

This context for the emergence of the ancient nomos is explained in a peculiarly structural passage, relating the need for such a legal world-framing to agrarian crises in the seventh to sixth centuries $\mathrm{BCE}$, demands for knowledge from the poorer classes, artisanal alliances, and the emergence of the demos (citizens, WtK, 121-29). The truth trajectory is clear here, from Gods, to Kings, to the people; from the sovereignty of the divine to the sovereignty of democracy (as discussed in the analytics of ethos below). But this demos needed a polis, a city, that could sustain justice through a true and accessible order, a nomos (this would also allow the city to be observed and known, one of the few hints at the visibility analytic at work here). Yet this trajectory was only ever a gradient, with the truth-justice relationship retaining traces of older truths in its many forms (WtK,120). Thus ancient rites of purification also become reworked, as did notions of justice, law and money, under the emerging conditions of political power. The city became a place in which order over life and death had to be established, containing the Draconian legitimation of the murder of a murderer by temporally limiting it to a singular counter-murder, not a family feud, and spatially orchestrating violence through law (the perpetrator of involuntary homicide was exiled, a murderer in exile could not be killed, WtK, 177). The parallels to Agamben's (1998) work on Roman Law and states of exception are striking here, as is the shared interest in the role of constitutive outsides and the 
sovereign-founding powers of abandonment. But these new laws also acted to purify the city, erasing the defilement of crime; not the Oedipal crime of murder and incest (for which he underwent self-expulsion), but the civic crime of a man offending the city. "He is excluded by the nomos, but he is excluded from the nomos, from the places where and forms in which it is exercised. His is thrust outside by the principle of distribution." (WtK, 181)

\section{The Government of the Living: infrastructures of the soul}

In the transitory 1980 lecture between Foucault's interest in Oedipus and the truth acts of early Christianity he re-affirmed that his interest was in the government of men [sic] through the manifestation of truth in the form of subjectivity $(\mathrm{GoL}, 80)$. He explained that this interest was in how individuals were obliged to become essential actors in the manifestation of truth, how they could be both operator, spectator and the object of truth acts. The first person here, therefore, is not just the witnessing or travelling "I", nor the subject of power ("...here I am, me who obeys") but also the subject of alethurgy ("...this is who I am, this is what I have seen, this is what I have done", $G o L, 82)$. The nature of this subject will be discussed in the following section, but first comes the techne of obligation: how could you be obliged to constantly seek out secrets of yourself that must elude you? How could you be made to manifest these secret truths into supposedly liberating effects? Foucault's direct and most well-known infrastructure for extracting this liberation was, of course, the confession (see Elden, 2005). But confession formed only part of the last of three forms of compulsion to manifest one's individual truth through complex relationships with others (and through the fear of God and Satan themselves) that Foucault studied, being: canonical (baptism); ritual (penance); and spiritual direction (monastic).

These incredibly detailed lectures, which make up two thirds of the course, outlined the individual's internalisation of the obligation to tell the truth. The techne here described is one of a religion attempting to establish itself in the face of persecution, and desperately attempting to discipline its followers into accepting, living, and speaking the truth of Jesus Christ. But what it also charts is the movement towards an examination of the self under the guidance of one or many others that links disciplined performative acts of the body to the compulsion to verbalise one's very own Christian truth.

Baptism, the first study, acted to admit purified souls to the Christian faith, though never cleansing them entirely of "original sin", the "marvellous idea" which Foucault (1979-80 [2014], 107, 122) suggested was invented by the early Christian theologian Tertullian (c. 155 - c. 240 CE). Constant vigilance and inner awareness and transformation were therefore vital, as: 
"... on the basis of the original fall, Satan has found a place for himself in the soul, in the soul of every man, he has established his empire at the heart of men's soul, and he has made of these souls, and of all of them, his own church. Each of our souls is, as it were, a little church within which Satan reigns and exercises his power." (GoL, 124)

Purification therefore had to happen before baptism, not through it. And the closer one got to purification the greater the devil resisted his expulsion, thus the harder one had to work to be pure: "... the more Christian one is, the more one is at risk. The more Christian one is, the more the devil rages. The closer one gets to the truth, to liberation, the more hostile, violent, furious, and dangerous the enemy." (GoL, 125) Christianity will be based on this founding anxiety, (which we could think of as a pre-modern, but still highly reflexive, "risk society", see Beck, 1992), in which one can never be certain about what one is oneself; a fear that is anchored in Christianity from the second and third centuries CE. The answer to this fear was the discipline of repentance (or metanoia, the turning of the soul towards the light) which could prepare one for the struggle of baptism. Its techne was that of a gymnastics of the soul and the body which would prepare them for their purification and their life-long struggle against Satan. This controlled period (the catechumenate) could last from months to years, and involved a private examination, a quizzing on the grounds for requesting accession to Christianity, accepting the rules of a Christian life, and the passing of a test at the end of the catechumenate, followed by a period of ascetism (fasting, vigils, kneeling and prayer) to test the rigour of faith and preparation for the baptismal battle with Satan (GoL, 149-50). It was from these "concrete techniques" (GoL, 155) that the second life after baptism began.

What, however, if one should fall in this new life? How true could the subject's truth be if he or she sinned from within this exposure to God's light? Could there be a metanoia internal to Christianity that allowed one to repent of one's sins? Could one continue to convert, to repent, within the Church? From the second to seventh centuries CE the possibility of this repetition of the pentitential part of baptism was created through the emergence of canonical penance; a second penance. In early forms this penance meant a stigma for life. The penitent would be the object of external examination but would also be the subject who would reflexively have to manifest their truth. The term applied to the latter performance was exomologèsis (the admitting of ones sin and the status of being a sinner, GoL, 202). This admission was, foremost, a theatrical one. The early penitent lived as an outcast, dressed in sackcloth and ashes, subject to fasting and theatrical, public expression of their sorrow; lingering outside the church door. 
But what both baptismal rites and penance lacked was a verbalization of sin by the sinner or a detailed journey of self-discovery. The key shift for Foucault was the transition between the seventh to eighth centuries from this performative but non-verbal penitence to a form of truth-telling (verbalising $\sin$ ) and transition of self (to the truth of oneself, GoL, 226). Penitence would come to take these forms via tariffed penance (from the 6th century $\mathrm{CE}$, being precisely determined penances for each offense, sanctioned by a priest. GoL, 323, also see Foucault, 1974-75 [2003], 1724, for an earlier examination of tariffed penance). But it would be in the monasteries where the verbal and the inner exploration would be perfectly united, in spiritual direction that involved submitting voluntarily to someone else's will. The aim would be the tranquillity of the soul, the absence of passions, self-control, and a certain relationship of self to self (or "subjectivation", GoL, 231-32 see the following section). This techne emerged in the fourth century CE, especially in the influential teachings of John Cassian (c.360-435 CE), where he explained the procedures for spiritual direction, the institutions and rules of monasteries, and the remedy of vices which he had observed in the holy lands and had brought back to the south of France.

The postulant in the monastery would be tested in his submission (to others), his patience (to the world) and his humility (to himself). The object of this techne was to create a subject who would obey everything and hide nothing; willing nothing by himself and telling all about himself to his spiritual director (GoL, 266). Specific acts would bring about specific bodily dispositions that would allow the realisation of inner truth: listening (obedience); speaking (confession); and looking (examination, a particular analytics of visiblity). Confession would allow internal examination and the rooting out of the devil within, shaming it with truth, banishing it with light, expelling it with speech (GoL, 306). This was not exomologèsis (the public performance of one's sin) but exagoreusis (an alethurgy of putting oneself into discourse, of verbalising truth, GoL, 307). The truth here is not the truth of fact, established by ancient coin, calendrical weather cycle or the taming of murder revenge; it is a truth one is encouraged to drag out of oneself using a techne of admission (baptism), regulation (penance) and disciplinary surveillance (direction). It is through the latter that Foucault claimed to be identifying the birth of the modern subject; the human that was the target of his career-long anti-humanism (a stance affirmed here, GoL, 80).

\section{Identity: the birth of you?}

\section{The Will to Know: the witness and the citizen}

In the Will to Know Foucault was explicit that his focus was a "critical" one, exposing the exclusions circulating through the "choice of truth", not a "genealogical" one, analysing subjects of truth. As such there is less on subjectivity or the identity of the governed in these lectures. What there is 
concerns the emergence of legal and political subject positions in the Archaic to classical Greek world. In terms of the former the most prominent is the witness. This is a figure who, in the third century BCE, is summoned, swears that a statement is true, testifies on what they have witnessed, and remains silent on what they have not $(W t K, 72)$. The techne of the nomos, alongside that of standardised measurements of space and time, meant that justice could normalise acts over space, meaning that every person had to be just: "He [sic] will be just insofar as he will have paid attention, pricked up his ears, and kept what is just in his memory. Justice is not only what is said, it is what is listened to; and the just man is not only the one who utters the good sentence, he is the man, every man who has listened to justice." (WtK, 109) The common man (the punctual debtor, the measured labourer) is just, and becomes the model and norm for whoever dispenses justice.

By the sixth to seventh centuries BCE these people were beginning to be called the demos which, given form by the City-State, begin to assume the form of a more familiar subjectivity in the polis: “... as a set of citizens insofar as they are possessors of a part of power and that power as a whole is exercised through them all... Power is what is exercised permanently through all the citizens. The totality of a social body begins to appear as the site where power is applied to itself. Power arises from a body on which it is exercised." (WtK, 160) But this is the subject of external power, a discursive placement in a broader apparatus of law and politics. It was through the techne of early Christianity that Foucault spoke most explicitly about the subject of truth.

\section{The Government of the Living: tell me who you are}

"What is this game of the myself or oneself within procedures of truth?" $(G o L, 67)$

"To obey and to tell all, to obey exhaustively and exhaustively tell what one is, to be under the will of the other and to make all the secrets of one's soul pass through discourse, so that the secrets of one's soul come to light and so that, in the ascent of the soul's secrets to the light, obedience to the other is total, exhaustive, and perfect..." (GoL, 266)

In summarising his broader interest in the Christian regime of truth Foucault suggested he was attempting a preliminary account of something he felt had never been analysed, namely, the history of "tell me who you are." (GoL, 146: for earlier comments on this notion see Foucault, 1978 [2013], 112) He believed this injunction was central to "Western civilization", and was being forged in this truth regime, as the soul was told to find the truth, which could only be achieved by telling another who you were. This injunction to find and then verbalise your inner-self marked a historical moment but also, it seems, a philosophical moment; a (not the) founding of a humanism that would 
accompany and undergird emergent western governmentalities over the next 1500 years. In teasing apart the techniques through which this human subject was actually created we can see Foucault continuing the anti-naturalism he elsewhere pursued in exposing sexuality as discursively created, the invisible hand of the economy as the product of state regulation, or madness as an epistemological counterpoint to Reason (see Legg, 2014, 36-39, also Harcourt, 2011).

Foucault's later reading of Oedipus emphasised the emergence of the witness, someone who can say "myself", a starting point of a path that would lead to Descartes, who could say "myself" with regard to mathematical truths. These mark "point[s] of subjectivation in the general procedure and overall cycle of alethurgy..." $(G o L, 73)$ and they are vital. Again and again Foucault stresses that his interest is in the government of men through the manifestation of truth in the form of subjectivity, articulating a double sense of the subject, "... subject in relation of power, subject as manifestation of truth..." (GoL, 80-81) Subject as operator, spectator and object of truth acts; subject that encapsulates the obligation to know and liberate themself; subject to confession; subject to fear of the sin within oneself, which was of "...decisive importance in the whole history of what we may call subjectivity, that is to say the relationship of self to self, the exercise of self on self, and the truth that the individual may discover deep within himself." (GoL, 127-28); and subjectivity as the mode of relation to self that coupled self-discovery to self-description, described through the emergent techne of confession.

Get the devil onto your tongue and he is already out of your heart; for monks this confession was perpetual and continuous ( $G o L, 306)$. The temptation to leap forward from the monasteries of the French Midi (then Southern Gaul) established by Cassian to Freud's couch in Vienna, in search of the modern talking cure, is one Foucault resists. But he clearly continues the link he had been making between broader governmentalities and subject formations in former lectures (the political subject of population discourses and the economic subject of liberalism), and sets the scene for the discussion of fearless speech and riskier truth talk of parrhesia in his final lecture courses (Foucault, 1982-83 [2010], 1983-84 [2011]).

\section{Ethos and problematisations: democracy, revolt, guilt, sin}

\section{The Will to Know: to the people}

Foucault famously refused to denounce the governmentalities he studied, but he did draw attention to their ethos (their valuings, distributions and biases) and the way in which they were problematized (the resistances they responded to and provoked). In terms of the former, his first lecture course was explicitly positioned as a course on exclusion via truth claims. Sophism was 
excluded from philosophy, just as truth challenges and appeals to the wild sovereignty of the gods were being supplanted by juridical truth claims and knowledge-based procedures of law. The ethos was one that was edging towards various democratic moments, supplanting tyrannical, gift-eating kings who sought to take, and know, too much, with the rule of the demos and a power that circulated through the capillaries of the polis. By the fifth century the philosophical and practical problem of democracy was churning and forming Athens: "In order to govern the city, does one need to transform those who do not know into those who know? Is it necessary to transform all those who do not know into people who know? Or in order to govern the city is there a certain knowledge that some need to possess, but not others?" (as summarised on his return to Oedipus in GoL, 56)

This does, of course, hint at the ethos of Athenian democracy, which excluded women, slaves, immigrants and others from the demos. If these groups did not present major problematizations to the truth and knowledge politics of classical Greece then Foucault makes it clear that the system emerged out of various clashes and uprisings, referencing the agrarian crises in the seventh and sixth centuries BCE and the violent clashes they led to, in the context of broader clashes between the hoi polloi (poor) and hoi ploutoi (rich, WtK, 127). It was the practice of democracy and the actuality and possibility of revolts which transformed Greek societies, but it was something else which presented Oedipus with his grand problematization, his desire for knowledge or, as later reconfigured, his blindness to truth.

\section{The Government of the Living: to the soul}

Half-way through Sophocles' Oedipus, Foucault recounts, comes a song of the chorus. Between the delivery of the elite truths of the gods and a queen, and the plebeian truths of a shepherd and a servant, comes this singing. It sings in praise of law and of Oedipus's saving of Thebes, but it also denounces tyrants: "the truth is on the move and rushing towards the stage,.. it has not yet arrived, [but] the chorus has already dropped Oedipus and given a negative picture of Oedipal power." (WtK, 62) The Government of the Living lectures therefore begin by recounting one regime that attempted to rule over knowledge at the cost of truth. All regimes need, however, an alethurgy, and Foucault recounts the creation of a Christian truth regime which, he suggests, would found the very subjectivation of Western civilisation. The ethos he describes is explicit: a Church which creates a battery of concepts (original sin, the church of Satan in the heart of the human body) with which to defend its fledging religion from rivals, enemies and imposters, and through which to insert itself into the bodies, beliefs and self-truths of its followers. 
So far, so depressing. Despite his earlier insistence that he hated power and that it was everywhere tracked by resistance, this appears to be Foucault at his most oppressive, seeing authority and its triumph everywhere. There is, however and as usual, plenty of evidence of counter-conducts and problematisations in the text, which outline why the regimes of truth had to be created in the first place. Here we get a roll call of teasing, testing and questioning subjects: from un-sanctioned ascetism in the Egyptian desert (GoL, 262); to subjects who would rather enjoy a life of sin and push back baptism until as late a date as possible $(G o L, 120)$; to the lapsed Christian forcing either ejection from the faith or a revision of its terms to allow ongoing penance $(G o L, 176)$. While the language describing spiritual direction (obey all, tell all) reads like some fascist nightmare, this is the language of injunction; a demand, or possibly a plea. Within the stone-walled confines of a seventh-century monastery this call may have been heeded, but outside the partitions of this disciplinary laboratory it would take centuries and endless mutations (see Foucault, 1977-78 [2007], 1979) for this command to speak one's truth to become the widespread desire to share and dissect our selfessentialisms, which feel so much like truths.

\section{Re-uniting the sumbolon: before and after governmentality}

"The will to know is the title I would like to give to this year's lectures. To tell the truth, I think I could also have given this title to most of the historical analyses I have carried out up until now." $(W t K, 1)$

"When I think back now, I ask myself what else it was that I was talking about, in Madness and Civilisation or The Birth of the Clinic, but power?" (Foucault, 1980, 115, from 1977)

"I would say that this has always been my problem: the effects of power and the production of "truth." (Foucault, 1977 [1990], 118)

“... I think it would... be very difficult to find an example of a power that is exercised without being accompanied, in one way or another, by a manifestation of truth." $(G o L, 4)$

In looking back on his work Foucault could clearly see it as always already having been about knowledge, about power, about truth; recaps which he referred to as a "turn of the spiral on what has been done." $(G o L, 80)$ The concept of ideology had been tackled head on by his 1970 s powerknowledge work (GoL, 75-78), although by 1980 he decided it had become a "...worn and hackneyed theme" $(G o L, 11)$. The shift he was now trying to induce was that from power-knowledge to the 
government by the truth. But was this "governmentality"? And given the clear interests in truth, knowledge and power in the Will to Know, was "governmentality" something that was already being studied in 1970 ? To the former proposition I would answer yes, to the latter, no.

The analysis above suggests certain continuities across Foucault's 1970s, but also suggest ways in which we could expand the current analytical toolkit to interrogate deeper and broader governmentalities, and their geographies. For instance: thinking about the agonistic struggles in the classical polis to help us analyse the struggles for freedom and movement in the neo-liberal and contemporary-democratic city; thinking about contemporary reformulations of the "tell me who you are" question in psychotherapy, social media, and children's spaces; thinking about anti-imperial forms of resistance and the way they fight for counter-truth-tellings through forms of memorialisation, narrativisation and alternative relations to self; using Foucault's method of reinterpreting Greek tragedy as a playing out of truths (by halves) as a way of analysing artistic representations and their relationships to their cultural, political and material spaces of composition; and, not least, suggesting to the vast array of authors thinking about the spatialities of regulation, intervention and calculation using governmentality studies to consider, in new ways, subjectivity, the nature of self-other relations, the types of truth-productions at play, and the creation of subjects of truth. Some direct connections between the lectures and governmentality more generally, and the questions they provoke, will now be briefly explored in conclusion.

\section{The Will to Know: the vertigo of a familiar past}

In the 1970-71 course Foucault was explicit about the linkages he forged between knowledge, truth and different forms of power. His challenge was articulated as that of putting the "...game of truth back in the network of constraint and dominations. Truth, I should say rather, the system of truth and falsity, will have revealed the face it turned away from us for so long and which is that of its violence." (WtK, 4, emphasis added) But if truth was involved in games of domination and violence, the will to truth had also crossed centuries of history as a type of division which governs our will to know (Foucault, 1970 [1981], 54). These opening lectures situate truth in an abstract sense between domination and governance.

In an historic sense we also see this situating of truth and knowledge between a world of dominance (the Archaic world) and emerging governance (the classical world). And it is here that one gets a dizzying sense of vertigo as Foucault takes us back into the unfathomably different world of ancient Greece and finds for us there something so completely familiar. Alongside dikazein emerged krinein; emerging in the cracks within an older sovereignty and eventually coming to normalise and marginalise it, here we see the emergence of a judicial and juridical model that, Foucault repeatedly 
asserts, is still with us today (Foucault, 1970 [1981], 70, 1970-71 [2013], 84, 189). Is what we are seeing here, then, the birth of a modern intertwining of sovereignty and the law that would eventually be augmented by disciplinary and governmental power in early modern Europe? Are we here witnessing the birth of that which Foucault insisted still needed decapitating as late as 1980; the compact of law, violence, sovereignty and the state, and its representation in political theory (Foucault, 1980, 121)? Did these lectures before the "governmentality" lectures of 1977-79 sketch out the world before governmentality that made it both possible and necessary?

\section{The Government of the Living: before fearless speech}

If the Will to Know lectures outline the birth of the sovereign-juridical pact that governmentality would emerge against, then does the Government of the Living constitute the early genealogy of the governmentalities that would emerge in Europe from the $16^{\text {th }}$ century onwards? Foucault clearly felt he was outlining the birth of western subjectivity, but could truth be used in as utilitarian fashion as knowledge within governmental apparatuses? Could it be that truth was the showy garb that cloaked the inner violence of power (pre-figuring Agamben, 2011, on power as government and ceremony, or The Kingdom and the Glory, in the history of governmentality)?

"Maybe. But can there be power without showy garb? In other words, can there really be a power that would do without the play of light and shadow, truth and error, true and false, hidden and manifest, visible and invisible? In other words, can there be an exercise of power without a ring of truth, without an alethurgic circle that turns around it and accompanies it?" $(\mathrm{GoL}, 17)$

So we can see truth claims being used within other forms of power which are here explicitly referred to as governmentalities. These encompassed the truths of: state reason; of society and economy; expert knowledge; of capitalism; to the forceful truth of oppressive regimes: "This is, precisely, the principle of terror. Terror is not an art of government the aims, motives, and mechanisms of which are hidden. Terror is precisely governmentality in the naked, cynical, obscene state. In terror it is the truth and not the lie that immobilizes." (GoL, 15) After this point the word "governmentality" is largely dropped in favour of "government" (of men, souls, others, the living) but the concept remains entirely consistent with definitions of governmentality offered up before.

So truth is taken up in governmentalities, and truth acts were encouraged. But there were also "truth regimes" that were more emphatically linked to one side of power (GoL, 93), which imposed acts of belief, professions of faith, or confessions with a purifying function. Foucault immediately situated these regimes within their broader governmentalities. His aim in the course was stated, 
explicitly, to be that of linking regimes of truth to other regimes. Juridical, political and truth regimes came together in more specific regimes of disease, delinquency, sexuality and, of course, Christianity (GoL, 101-02).

This line of thinking offers up various ways of linking this course to other governmentality work. Not only the spread of confession from the monasteries to the churches and clinics of the modern world, but also the liberal genealogy of willingly entering into relationships with directors who will tell you what to will (GoL, 229). But, as so often with the post 1976-77 lecture courses, the aim of situating the Christian alethurgies of baptism, penance and spiritual direction within their political and juridical regimes remained unfulfilled in the Government of the Living, but not in the following year's supplementary lecture course Wrong-Doing, Truth-Telling: the Function of Avowal in Justice (where the truth-tests of oath taking were shown to have re-emerged in the Middle Ages in the shape of the inquisition and of torture Foucault, 1981 [2014], also see Valverde, forthcoming)

Yet Foucault concluded the Government of the Living with a wholly explicit rendering of alethurgy within the more political tilt of governmentality. Jettisoning any mention of resistance or counterconducts, he suggested that the Christian is "yoked" to the deep secret of their own truth, bent over it and constrained by it, forming one of our most basic forms of obedience (GoL, 312-313). This, he suggested, is the kernel of the western subject's obsessive quest to know the truth of their humanity; not so as to rid Thebes of the plague or to deny an incestuous and parricidal prophesy, but to answer the capillary and normalised command "tell me who you are." If you feel the need to respond, Foucault suggests, then maybe there's a bit of Oedipus in you too. 


\section{References}

Agamben, G. (1998) Homo sacer: sovereign power and bare life. Stanford University Press: Stanford, California

Agamben, G. (2011) The Kingdom and the Glory: For a Theological Genealogy of Economy and Government. Stanford University Press: Stanford

Barnett, C. (2011) Is governmentality a dirty word? https://clivebarnett.wordpress.com/2011/11/15/is-governmentality-a-dirty-word/ [accessed 16th June 2015].

Beck, U. (1992) Risk society: Towards a new modernity. Sage: London

Behrent, M. C. (2012) The Genealogy of Genealogy: Foucault's 1970-1971 Course on The Will to Know Foucault Studies 13, 157-178.

Bernauer, J. W. and Mahon, M. (2005) Michel Foucault's ethical imagination. In The Cambridge Companion to Foucault. (Ed, G. Gutting) Cambridge University Press, Cambridge, pp. 149-175

Burchell, G., Gordon, C. and Miller, P. (1991) The Foucault effect: studies in governmentality. Harvester Wheatsheaf: London

Crampton, J. and Elden, S. (Eds.) (2007) Space, Knowledge, and Power: Foucault and Geography, Ashgate, Aldershot.

Davidson, A. I. (2005) Ethics as Ascetics: Foucault, the History of Ethics, and Ancient Thought. In The Cambridge Companion to Foucault. (Ed, G. Gutting) Cambridge University Press, Cambridge, pp. 123148

Elden, S. (2005) The problem of confession: the productive failure of Foucault's History of Sexuality Journal for Cultural Research 9, 23-41.

--- (2007) Rethinking governmentality Political Geography 27, 29-33.

--- (forthcoming-a) Foucault: The Birth of Power. Polity Press: Cambridge

--- (forthcoming-b) Foucault's Last Decade Polity Press: Cambridge

Ettlinger, N. (2011) Governmentality as Epistemology Annals of the Association of American Geographers 101, 537-560.

Foucault, M. (1970-71 [2013]) Lectures on the Will to Know: Lectures at the Collège de France 197071 and Oedipal Knowledge. Palgrave Macmillan: London

--- (1970 [1981]) The order of discourse. In Untying the text: a poststructuralist reader. (Ed, R. Young) Routledge \& Kegan Paul, London, pp. 48-78

--- (1973 [2001]) Truth and juridical forms. In Essential works of Foucault 1954-1984, volume 3: power. (Ed, J. D. Faubion) Penguin, London, pp. 1-89

--- (1974-75 [2003]) Abnormal: Lectures at the Collège de France, 1974-1975. Picador: New York

--- (1977-78 [2007]) Security, Territory, Population: Lectures at the Collège de France 1977-78.

Palgrave Macmillan: Basingstoke; New York

--- Foucault, M. (1978 [2013]) Michel Foucault and Zen: a stay in a Zen temple (1978). In Religion and Culture: Michel Foucault. (Ed, J. Carrette) Taylor \& Francis, London, pp. 110-114

--- (1978-79 [2008]) The Birth of Biopolitics: Lectures at the Collège de France, 1978-79. Palgrave Macmillan: Basingstoke

--- (1979) The History of Sexuality Volume 1: the Will to Knowledge. Allen Lane: London

--- (1979-80 [2014]) On the Government of the Living: Lectures at the Collège de France 1979-1980.

Palgrave Macmillan: Basingstoke

--- (1980) Power/Knowledge: Selected Interviews and Other Writings, 1972-1977. Harvester Press:

Brighton

--- (1981 [2014]) Wrong-Doing, Truth-Telling: The Function of Avowal in Justice. University of Chicago Press

--- (1982-83 [2010]) The Government of Self and Others: Lectures at the Collège de France 19821983. Palgrave: Basingstoke 
--- (1983-84 [2011]) The Courage of Truth: Lectures at the Collège de France 1983-1984. Palgrave: Basingstoke

--- (1977 [1990]) Power and Sex. In Politics, Philosophy, Culture: Interviews and Other Writings, 19771984. (Ed, L. D. Kritzman) Routledge, pp. 110-124

Foucault, M., Gordon, C. and Patton, P. (2012) Considerations on Marxism, Phenomenology and Power. Interview with Michel Foucault; recorded on April 3rd, 1978 Foucault Studies 14, 98-114.

Fuggle, S. (2013) Foucault/Paul: Subjects of Power. Palgrave Macmillan: London

Gordon, C. (2014) Plato in Weimar, Weber revisited via Foucault: two lectures on legitimation and vocation Economy and Society 43, 494-522.

--- (2015) The Christian art of being governed Foucault Studies 20, 243-265

Harcourt, B. E. (2011) The illusion of free markets: punishment and the myth of natural order. Harvard University Press: Cambridge, MA

Howell, P. (2007) Foucault, Sexuality, Geography. In Space, Knowledge, and Power: Foucault and Geography. (Eds, J. Crampton and S. Elden) Ashgate, Aldershot, pp. 291-316

Koopman, C. (2013) The Formation and Self-Transformation of the Subject in Foucault's Ethics. In $A$ Companion to Foucault. (Eds, C. Falzon, T. O'Leary and J. Sawicki) Wiley-Blackwell, Chichester, pp. 526-543

Legg, S. (2005) Foucault's Population Geographies: Classifications, Biopolitics and Governmental Spaces Population, Space and Place 11, 137-156.

Legg, S. (2009) An 'Indispensable Hypodermis'? The role of scale in The Birth of Biopolitics Journal of Cultural Economy 2, 219 - 225.

--- (Ed.) (2011) Spatiality, Sovereignty and Carl Schmitt: Geographies of the Nomos, Routledge, London.

--- (2014) Prostitution and the ends of empire: scale, governmentalities and interwar India. Duke University Press: Durham, NC

Legg, S. and Brown, M. (2013) Moral regulation: historical geography and scale Journal of Historical Geography 42, 134-139.

McSweeney, J. (2007) Foucault and Theology. Foucault Studies 2, 117-144.

Nally, D. and Taylor, S. (2015) The politics of self-help: The Rockefeller Foundation, philanthropy and the 'long' Green Revolution Political Geography 49, 51-63.

Ojakangas, M. (2010) On the Pauline roots of biopolitics: Apostle Paul in company with Foucault and Agamben Journal for Cutural and Religious Theory 11, 92-110.

--- (2012) Michel Foucault and the enigmatic origins of bio-politics and governmentality History of the Human Sciences, 0952695111426654.

Ormand, K. (2013) Foucault's History of Sexuality and the Discipline of Classics. In A Companion to Greek and Roman Sexualities.John Wiley \& Sons, Ltd, pp. 54-68

Philo, C. (2012) A 'new Foucault' with lively implications - or 'the crawfish advances sideways' Transactions of the Institute of British Geographers 37, 496-514.

Rutherford, P. and Rutherford, S. (2013a) The Confusions and Exuberances of Biopolitics Geography Compass 7, 412-422.

Rutherford, S. and Rutherford, P. (2013b) Geography and Biopolitics Geography Compass 7, 423-434. Said, E., Beezer, A. and Osbourne, P. (1993 [2004]) Orientalism and after. In Power, politics and culture: interviews with Edward W. Said. (Ed, G. Viswanathan) Bloomsbury, London, pp. 208-232

Schlosser, K. (2008) Bio-Political Geographies Geography Compass 2, 1621-1634.

Schmitz, T. (2008) Modern Literary Theory and Ancient Texts: An Introduction. Wiley: London

Valverde, M. (forthcoming) The forensic roots of the scientific revolution: truth-seeking and truthtelling from Oedipus to modern psychology Law \& Social Inquiry.

Veyne, P., Porter, C. and Davidson, A. I. (1993) The final Foucault and his ethics Critical Inquiry, 1-9. 


\footnotetext{
${ }^{1}$ These interpretations are based on two academic-year long reading groups at the University of Nottingham. The first (on the $W t K$ ) was organised by Stefanie Petschick from Critical Theory, with regular contributions by Benjamin Thorpe and Felix de Montety from Geography. I organised the second (on the GoL) with Greg Hollin from the Institute for Science and Society, with regular contributions from Lynn Fotheringham from Classics.
} 